\title{
Income Inequality in the United States and Europe
}

\author{
Harshit Gupta, Devang Garg, Shivansh Garg
}

\begin{abstract}
This paper concentrates on comparing the policies implemented in the United States of America and European Union after the 1960s which led to the inequality tends among the respective populations. Data comparison between the top $1 \%$ and bottom $50 \%$ households show significant increase in inequality in US whereas Europe has been successful in stabilizing these trends. Various factors such as role of European Union, role of Labour unions, Education, tax, and transfer policies are thoroughly explained with relevant data from various sources.
\end{abstract}

Keywords: Income inequality Economics Gini Coefficient Taxation Disparity Labour Capitalist

\section{Introduction}

In economics, income inequality is the significant disparity in distribution of income among the different sectors of the population. Income difference may be a natural result of individual performance of individuals. Individuals nonuniformity in talent and energy can end up in a spread of income results and consequently in a certain level of overall inequality. Income, being the major factor determining the quality of life, affects the health and well-being of individuals and their families. On global level, income inequality is extreme where the top $1 \%$ people of world are earning equivalent to bottom $56 \%$. Among other developed countries, income inequality is much greater in the USA. Since 1979, owing to the erosion of wages for less educated and disproportionate tax rates benefiting richer households, the income has increases by $275 \%$ for top $1 \%$ and only by $18 \%$ for the bottom $5 \%{ }^{[1]}$.

\section{Inequality in Developed Nations}

It is often observed that rich nations have lower economic inequality as compared to poor or developing countries ${ }^{[2]}$. The welfare capitalism model of the Nordic nations shows to have one of the lowest inequalities in the world. Gini coefficients are a mathematically computed quantity to give an estimate on inequality. Higher the Gini coefficient, higher is the inequality observed. The trends for the same can be shown here by the table and clearly most of the developed nations like in North America and Europe have low Gini coefficients thus lower inequality. The extent of development in each area is clearly shown by the per capita income of the areas.

\begin{tabular}{l|l|l|}
$\begin{array}{l}\text { Average Gini Coefficient and GDP Per Capita } \\
\text { By Region in } 2010\end{array}$ \\
\hline & $\begin{array}{l}\text { Average Gini } \\
\text { Coefficient }\end{array}$ & $\begin{array}{l}\text { Average GDP } \\
\text { Per Capita }\end{array}$ \\
\hline $\begin{array}{l}\text { Latin America and } \\
\text { the Caribbean }\end{array}$ & 48.82 & $\$ 6,443.76$ \\
\hline Africa & 44.26 & $\$ 1,136.30$ \\
\hline East Asia and Pacific & 37.40 & $\$ 9,672.39$ \\
\hline U.S. and Canada & 37.07 & $\$ 47,910.68$ \\
\hline Europe & 31.30 & $\$ 38,826.47$ \\
\hline $\begin{array}{l}\text { Eastern Europe and } \\
\text { Central Asia }\end{array}$ & 30.65 & $\$ 4,317.20$ \\
\hline
\end{tabular}

Source: World Bank
US alone has a Gini coefficient of $41 \%$. This high coefficient makes US an anomaly amongst the developed nations. The low tax rates have made the firm owners very well off and rewarded top earners, thereby also promoting growth of entrepreneurship, and making the richer people even richer.

\section{Causes of income inequality}

There are a number of reasons for the high inequality observed. Some of them are reasons that can be used as contradictions between USA and Europe. We try to list all of them together.

\section{Inflation}

Inflation is one of the major concerns for economists worldwide. It reduces the net income of individuals and high rates of inflation are especially crippling for the poor. Besides that, inflation is also found to have a negative impact on inequality. Rising inflation is seen to further increase the inequality in a nation. According to the article "The Impact of Inflation on the Income Inequality of Bangladesh: A Time Series Analysis", that for each one percent increase in inflation, inequality rises by about five percent ${ }^{[3]}$.

This relation can be attributed to the fact that the people with higher income can still see off the inflation over time as a small percentage increase in their wages is also a high amount. But the lower income population gets entrapped in poverty as their effective incomes get lowered. In the abovementioned paper, it has also been shown that prices rise more quickly for those with lower incomes.

Over the past many years, it has been observed that the inflation rates are more in the United States than most of the developed countries in Europe. This further adds to the higher income inequality in USA over Europe overtime.

\section{Productivity and Compensation}

Most Americans believe that as the economy expands, the rewards should be reaped by everybody. In the post- world war era, this was how the economy worked for about 25 years. The pay of the workers rose in proportion with productivity i.e., it was an efficient economy and Americans benefited from the better pay. But this started to change in the late $1970 \mathrm{~s}^{[4]}$.

Income inequality has increased over the three or more decades since the late 1970 s or more due to these three 
dynamics: rising inequality of capital income, rising inequality of labor income and increasing share of income going to capital income rather than labor income. As a result, the top $1 \%$ of households have $59.9 \%$ of the income gains from 1979-2007, while the bottom $90 \%$ has only $8.9 \%$ of income gains. (Mishel and Bivens 2011) ${ }^{[5]}$.

From 1979 to 2018, net productivity increased by 69.6 percent, while worker pay increased by only 11.6 percent over the same period. This demonstrates that, while productivity has been higher than ever, the benefits have primarily benefited the wealthy. The economy's productivity increased by 80.4 percent between 1973 and 2011, but the median worker's real hourly compensation increased by only 10.7 percent, with nearly all of that growth occurring in a brief window in the late 1990s. From 1948 to 1973 , the average worker's hourly wage increased in lockstep with productivity $^{[5]}$.

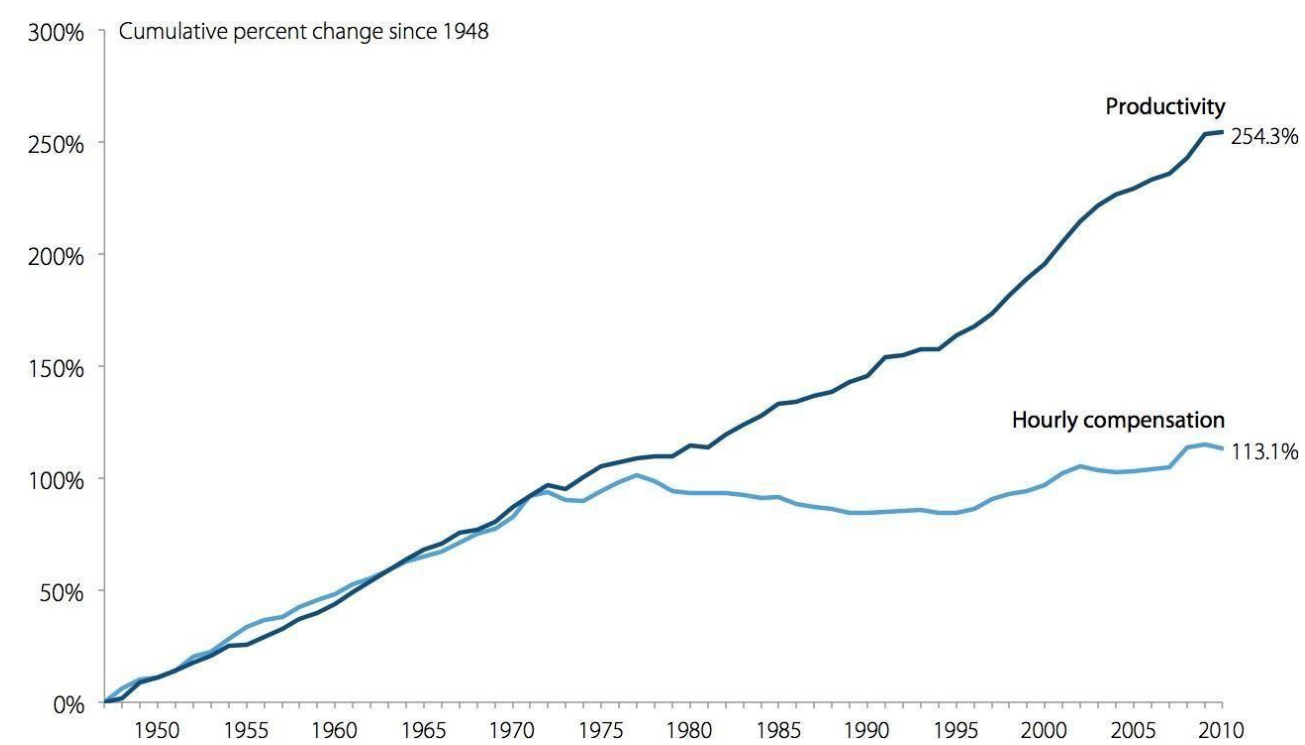

Hourly compensation is of production/nonsupervisory workers in the private sector and productivity is for the total economy. Source: Author's analysis of unpublished total economy data from Bureau of Labor Statistics, Labor Productivity and Costs program and Bureau of Economic Analysis, National Income and Product Accounts public data series

Productivity growth has frequently been identified as the source of our ability to improve living standards. Indeed, increased productivity is an important goal, but it only establishes the potential for higher living standards, as the experience of the last 30 years or so has demonstrated. Between 1973 and 2011, the economy's productivity increased by 80.4 percent, but the median worker's real hourly compensation increased by only 10.7 percent, with nearly all of that growth occurring in a short window in the late 1990s. The pattern was very different from 1948 to 1973, when a typical worker's hourly wage increased in lockstep with productivity. Restoring the link between productivity and pay for the average worker is an essential component of any effort to provide shared prosperity, and it may even be required for achieving robust growth without relying on asset bubbles and increased household debt. It is difficult to see how reestablishing a link between productivity and pay can happen without restoring decent and improved labor standards, raising the minimum wage to half the average wage, and making workers' ability to obtain and use collective bargaining a reality ${ }^{[5]}$.

\section{Education}

Income differences due to the difference in level of education has increased in recent years. The skill and knowledge gained through an academic degree translates into an individual's occupational qualification which leads to higher salaries. The post-industrial development of the United States has led employers to look for expertise in areas that was not required a few decades ago, while the manufacturing sector that requires not so high qualifications is decreasing in size.

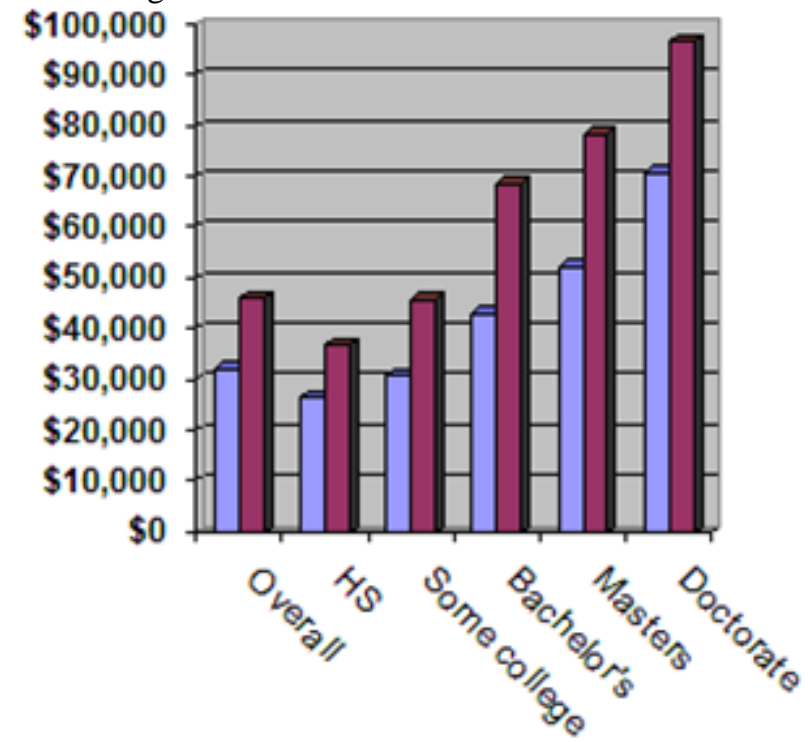

\section{$\square$ Persons $\square$ Households}

Median personal and household income according to different education levels

https://web.archive.org/web/20061009023311/http://www.ce nsus.gov/hhes/income/histinc/p16.html

In today's job market, the difference in income between professionals with higher academic degrees and working class is growing steadily. The average earnings for the 
population in 2002 increased with each level of education. This trend can be seen in most of the subgroups too. Within each specific level, the income was different on the basis of sex and gender. The term "college premium" refers to the higher income of workers with college degrees relative to those without. As the demand for college-educated workers has increased, the college premium doubled from 1980 to
2005. The increase in economic returns to education was the major cause of increase in wage inequality between 1973 to 2005. The lower capacity of lower income family children to verbalize concepts also played a role in the low achievement for higher education of these children ${ }^{[6]}$.

Table I Proportion of 25-34-year-olds by highest grade completed (Source: 'Table A-I Years of school completed by people 25 years and over, by age and sex: Selected years 1940 to 2007' found at: http://www.census.gov/population/socdemo/education/tabA-I.pdf)

\begin{tabular}{|c|c|c|c|c|c|c|c|c|}
\hline \multirow[b]{2}{*}{ Year } & \multicolumn{7}{|c|}{$\begin{array}{l}\text { Proportion of } 25 \text { - } 34 \text {-year-olds by } \\
\text { highest grade completed }\end{array}$} & \multirow{2}{*}{$\begin{array}{l}\text { Proportion } \\
\text { of } 17 \text { - } \\
\text { year-olds }\end{array}$} \\
\hline & A & $B$ & $C^{*}$ & $D^{*}$ & $E$ & $F$ & $G$ & \\
\hline & $\begin{array}{l}<8 \\
\text { Years }\end{array}$ & $\begin{array}{l}8-12 \\
\text { (no high } \\
\text { school } \\
\text { diploma) }\end{array}$ & $\begin{array}{l}<\text { High } \\
\text { school } \\
\text { graduate } \\
\text { (column } \\
A+B \text { ) }\end{array}$ & $\begin{array}{l}\text { High } \\
\text { school } \\
\text { graduate } \\
\text { only }\end{array}$ & $\begin{array}{l}>\text { High } \\
\text { school }\end{array}$ & $\begin{array}{l}>\text { High } \\
\text { school } \\
\text { graduate } \\
\text { (column } \\
D+E \text { ) }\end{array}$ & $\begin{array}{l}\text { At least } \\
\text { college } \\
\text { graduation }\end{array}$ & $\begin{array}{l}\text { High } \\
\text { school } \\
\text { diploma }\end{array}$ \\
\hline 2007 & 0.042 & 0.087 & 0.129 & 0.286 & 0.585 & 0.871 & 0.310 & n.d. \\
\hline 2000 & 0.038 & 0.081 & 0.118 & 0.306 & 0.576 & 0.881 & 0.293 & 0.703 \\
\hline 1990 & 0.044 & 0.093 & 0.138 & 0.408 & 0.454 & 0.862 & 0.239 & 0.739 \\
\hline 1980 & 0.048 & 0.098 & 0.146 & 0.395 & 0.458 & 0.854 & 0.241 & 0.714 \\
\hline 1970 & 0.091 & 0.171 & 0.262 & 0.440 & 0.298 & 0.738 & 0.158 & 0.759 \\
\hline 1960 & 0.195 & 0.225 & 0.420 & 0.358 & 0.222 & 0.580 & 0.110 & 0.679 \\
\hline 1950 & 0.273 & 0.214 & 0.487 & 0.324 & 0.146 & 0.470 & 0.053 & 0.590 \\
\hline 1940 & 0.424 & 0.213 & 0.637 & 0.220 & 0.133 & 0.354 & 0.060 & 0.508 \\
\hline
\end{tabular}

Notes: Starting in 2001, data are from the expanded CPS sample and were created using population controls based on Census 2000 data. Beginning with data for 1992 a new question was asked that resulted in different categories than for earlier years. Data shown as 'High School, 4 years' is now collected by the category 'High School Graduate'.

* In these columns (C and D) 'high school graduate' can include people with a GED (General Education Diploma).

The rise in income inequality in the United States over the last generation had only a minor impact on rising inequality in education. Government spending on education has helped to mitigate any potential increase in schooling inequality caused by rising income inequality. In Europe, the government spending supports the education, and a greater part of the education (upto high school) is quite cheap.

Reducing income inequality is not a promising way of reducing education inequality and reducing education inequality is not a promising way of reducing income inequality. Reducing income inequality, in particular, necessitates redistribution, either through the tax and transfer system or through wage controls. Differences in inequality among rich countries are primarily due to differences in post-tax and transfer income rather than differences in education or labor income. The Gini coefficient of market income is fairly similar across rich countries ${ }^{[7]}$.

\section{Tax and Transfer Policies}

Simply implementing the same tax laws won't have the desired effect of changing inequality. For example, if every household in the US is required to pay the same share of their income in federal taxes, then the post-tax income distribution would be the same as the pre-tax income distribution. But if higher-income households were to pay higher taxes than the middle- and low-income households, then the post -tax income of rich households will be greatly reduced as compared to the income of middle- and lowincome households. Thus, the after-tax distribution would be more uniform than the pre-tax distribution. This shows that the tax code makes a difference only when households with different incomes are required to pay different tax rates.

This shows that the more progressive the tax law is, the more it will reduce income inequality. On the other hand, a regressive tax law could exacerbate income inequality. Since 1979, the federal tax code in the US has been progressive with overall tax increasing with household income. In 2007, 
the pre- tax Gini index was 0.524 and the post-tax Gini index was 0.489 . That is approximately a reduction of $7 \%$ and thus shows that the tax code in the US has reduced income inequality to some extent ${ }^{[8]}$.

It is important to note that taxation is not the only way the federal government directly effects the income inequality. Other benefits such as insurance for unemployment or Social Security also helps to reduce inequality. The programs that provide 'in kind' substitutes for income, know as 'transfers', helps in renting housing assistance, nutrition assistance, etc. In fact, these 'transfer' programs reduce income inequality more significantly as compared to taxes. Before this assistance, the Gini index for US household income distribution was 0.59 in 2007. Government assistance reduced it by 11.2 percent to $0.524^{[8]}$.

Since the early 1980s, there have been some changes in the tax code of the US. Some of these changes have been progressive, while some of them have been regressive, i.e., tax cuts to benefit the rich. These changes had a major impact on the income inequality in the US. These changes can be categorized in different time intervals,

\section{Early 1980s}

In the early 1980s, President Ronald Reagan introduced some major tax cuts that benefited those with higher incomes. The total federal tax rate for the richest $1 \%$ declined from $37 \%$ in 1979 to $26 \%$ in 1986 . For the middle $20 \%$ income earners the tax rates remained the same and for the bottom $40 \%$ income earners, the taxes actually went up. This resulted in a significant decrease in the impact of the federal tax system on income inequality. This can be seen because the after-tax income distribution was 11 percent more equitable than the pre-tax distribution in 1979, but only 5 percent more equitable in 1986. Furthermore, in 1979 , the rich's after-tax share of income was $24 \%$ less than their pre-tax share, whereas in 1986, the rich's after- tax share of income was only $6 \%$ less than their pre-tax share ${ }^{[8]}$.

In 1986, Congress passed a tax reform in order to increase the power of the federal tax system to reduce income inequality. The reform helped to lower the top marginal tax rate and raised the investment income tax for rich households. The effective tax rate for the richest $1 \%$ increased by approximately 6\% while the bottom $60 \%$ received small tax cuts. This made the distribution of income more equitable and reduced the Gini score by $7 \%$ in 1987 as opposed to the score of 5\% in 1986.

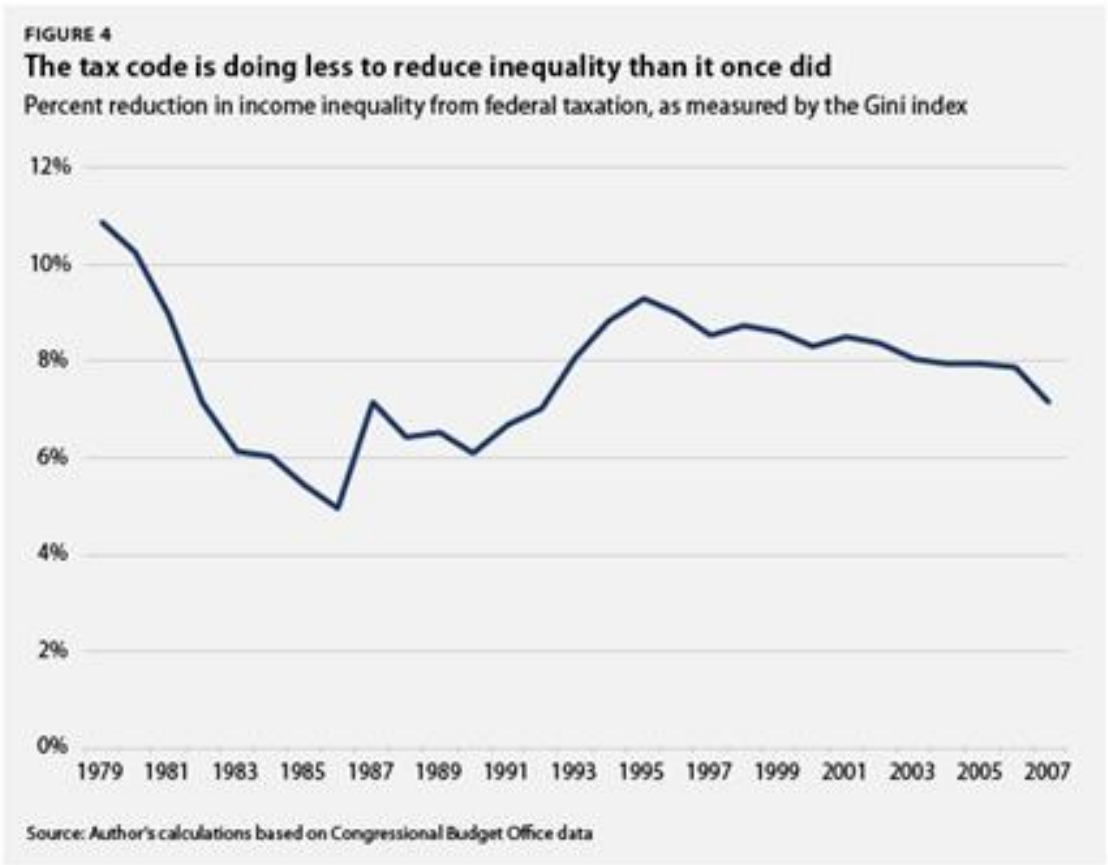

\section{Tax hikes of the early 1990s}

In the early 1990s, major federal deficit-reduction packages were introduced which included tax increases, especially the top marginal income tax rate. The purpose of both the packages was to boost the impact of taxes on income inequality. From 1990 to 1995 , the Gini index of the reduction in inequality grew from $6 \%$ to $8.5 \%$. The federal taxes in 1995 reduced inequality as much as those in 1979 $[8]$. 


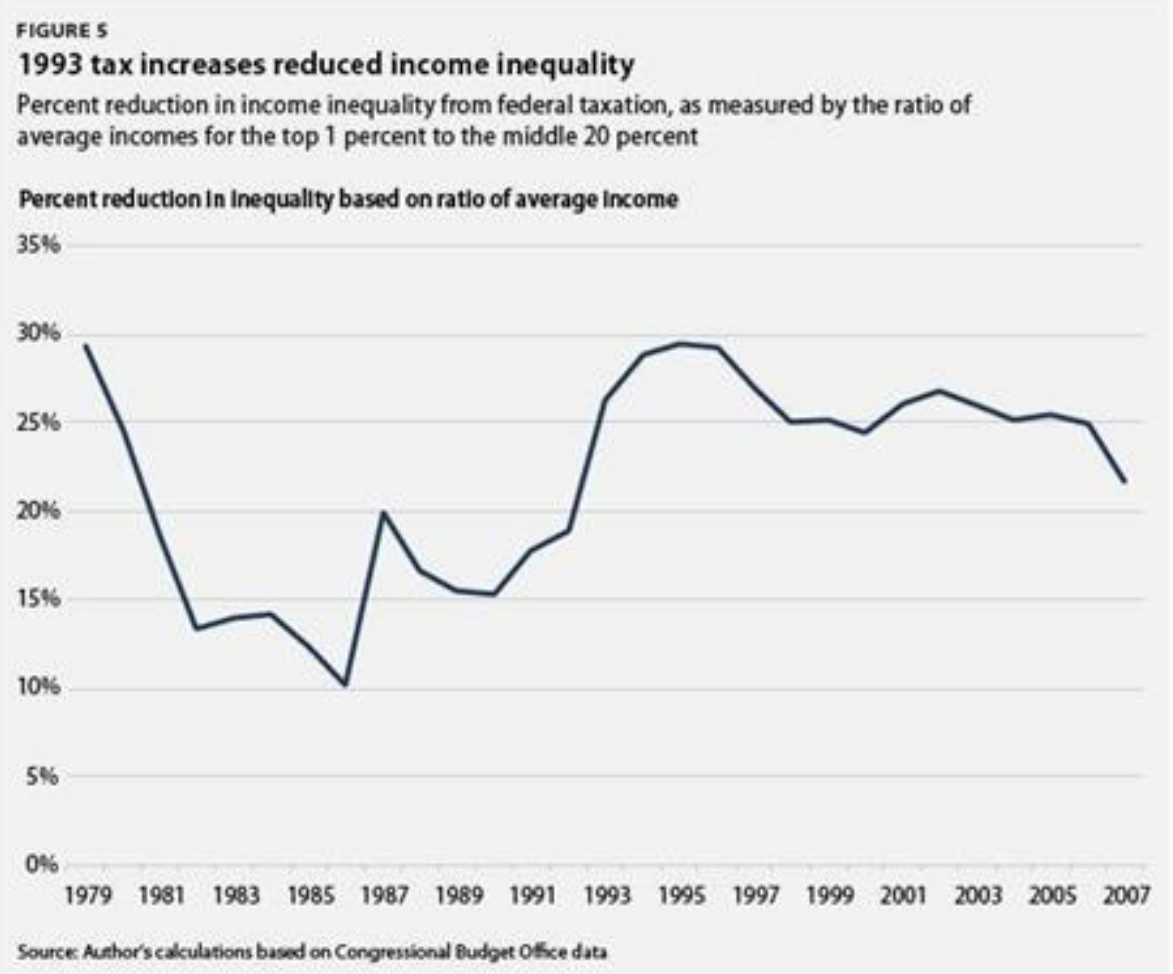

In 1997, the government passed a budget package which included a tax cut and was regressive in nature. The major component was the reduction in rates for capital gains as opposed to salaries. Four years later, there was another regressive tax cut package and then again in 2007. This led to the decrease in taxes paid by richest $1 \%$ households from $36 \%$ in 1996 to $29.5 \%$ in 2007.

\section{Critical Importance for Rich $1 \%$}

By examining the changes in tax policies in three decades, it can be seen that the thing which is most crucial for determining how effective the tax code is at reducing income inequality is the tax rate of the richest $1 \%$ households. When the effective tax rate for the wealthy rises, so does the tax code's impact on inequality, and vice versa. This can be seen in the chart below ${ }^{[8]}$.

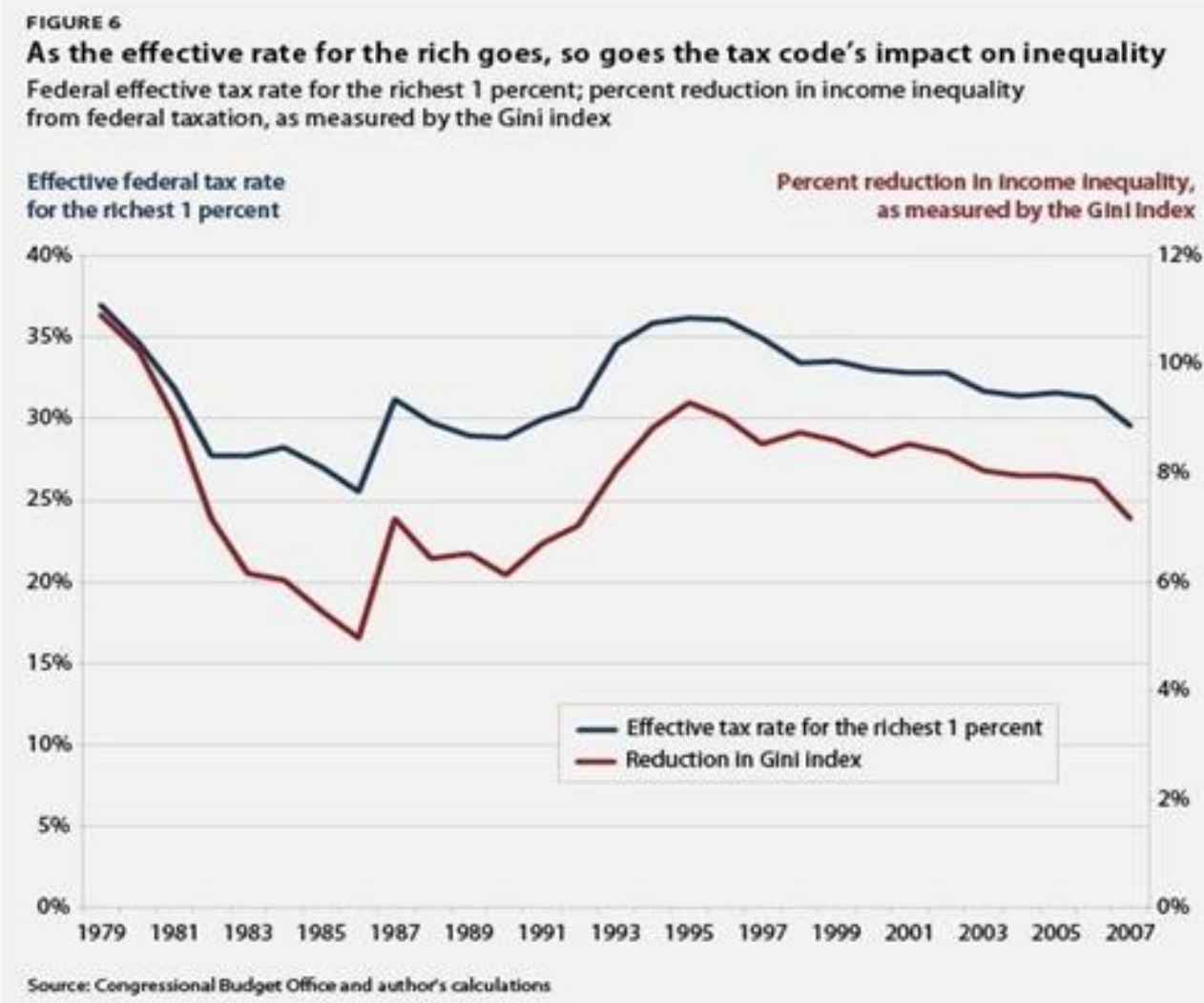


It can be also seen that the increasing share of taxes paid by the rich households is not a sign of progressivity (as the trend keeps on changing with time) but instead tells us about the increasing income of these households.

\section{History of Labour Unions}

The existence of public unions in any democracy including The United States of America and European nations is quite common. These unions, in particular, the Labour Union works for the benefit of the common people and the labour of the country's markets. These include workers' benefits, protection of their rights, better wages and healthy working conditions for all labour irrespective of their caste, race, religion etc. These unions are found to be stronger in socialist countries than capitalist nations. The clear importance of unions can be seen in the given picture.

\section{Unions Keep Inequality in Check}

\author{
Fewer workers are unionized today. \\ $\mathbf{3 0 \%}$ in 1955 \\ 11\% in 2017 \\ That's a problem because:
}

\section{Unions win higher wages for their workers.}

\section{$10-20 \%$} than nonunion workers, over the past 80 years.

Naition. Source: Henry Farber, Dan Herbst, llyana Kuziemko, and Suresh Naidu, "Unions and Inequality Over
the Twentieth Century," May 2018 . "Unions and Inequality Over the Twentieth Century," May 2018 .
2018 Infographic. Tracy Matsue Loeffelholz.

\section{People of color benefit most.}

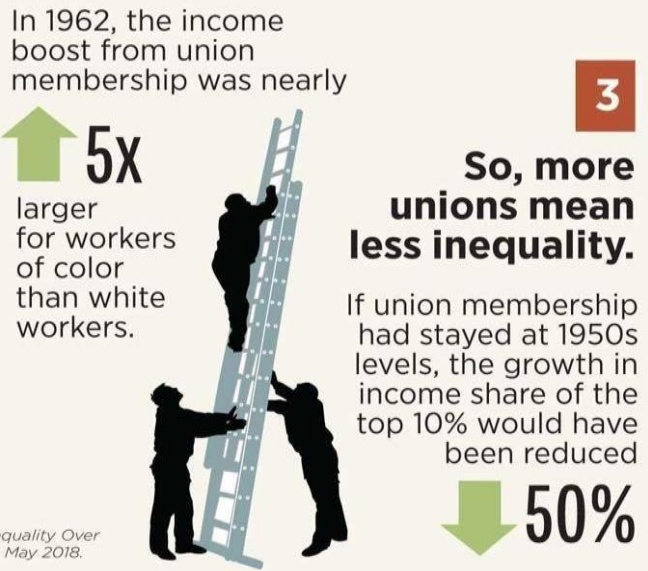

Source: There is Power in a Union (Mike Konczal, 2018)

Both USA and Europe had socialist regimes post World War 2. This was followed since the capitalist economy had failed miserably in 1930s and Keynes theories brought the countries' economy back on track. In all the socialist countries, the respective Labour Party was in power and so labour unions became powerful everywhere in both USA and Europe alike. In 1970s stagflation was seen in USA. Since the Keynes model was not able to alleviate the problem, the then president of the United States Ronald Reagan reduced taxes and transformed American socialist economy into a capitalist one. Due to this, the strength of labour unions decreased, and the socialist workers lost power. The change of job profiles from secondary to tertiary sector in the US over time further led to the decline of the unions. The income of the labour grew very little overtime as compared to the top executives whose income just skyrocketed during 2000s. Due to the growth of the capitalist regime in 1970s in the US, inequality also rose.

The graph clearly shows how the top $1 \%$ income share (good measure of inequality) rises when labour unions fall as before 1940 and after 1980

\section{US union membership and income inequality}

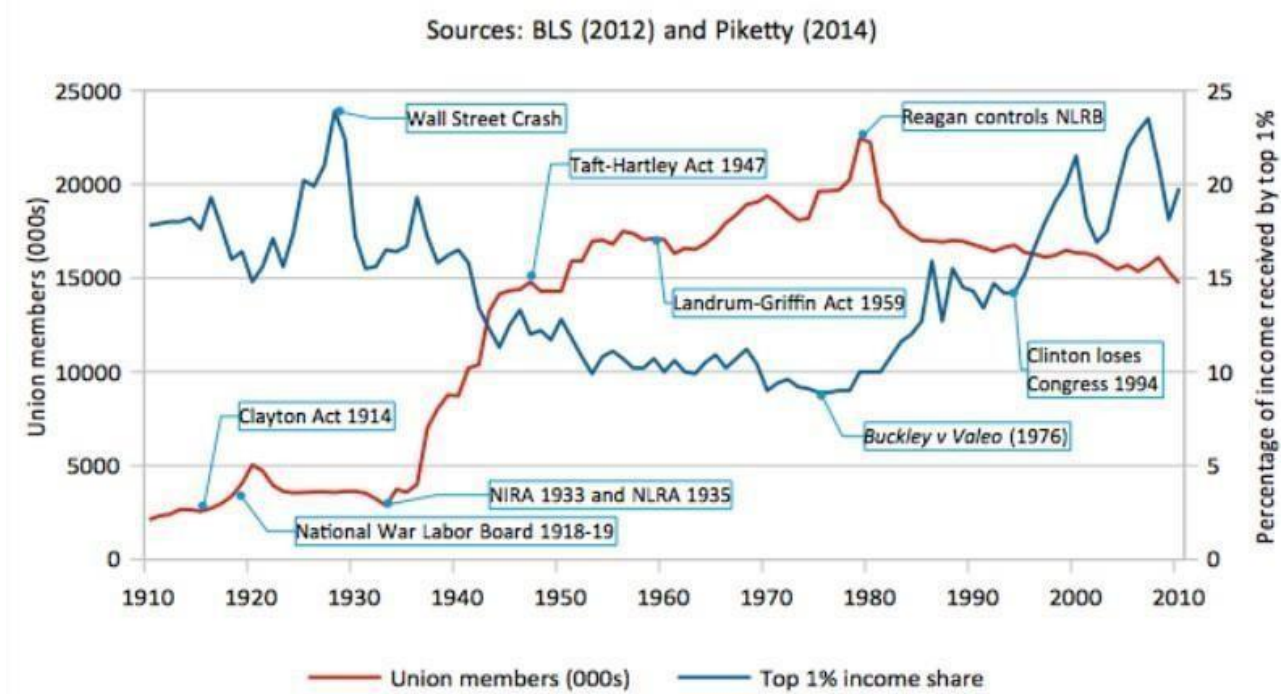

Volume 8 Issue 8, 2021

www.jissr.net 
Unions did not weaken much in Europe despite the advent of capitalism as the European nations focus heavily on social welfare. In countries like Germany and Sweden, labour unions are an integral part even today of corporate governance. The strong dominance of unions in Europe is a strong factor for better labour conditions and less inequality as compared to USA.

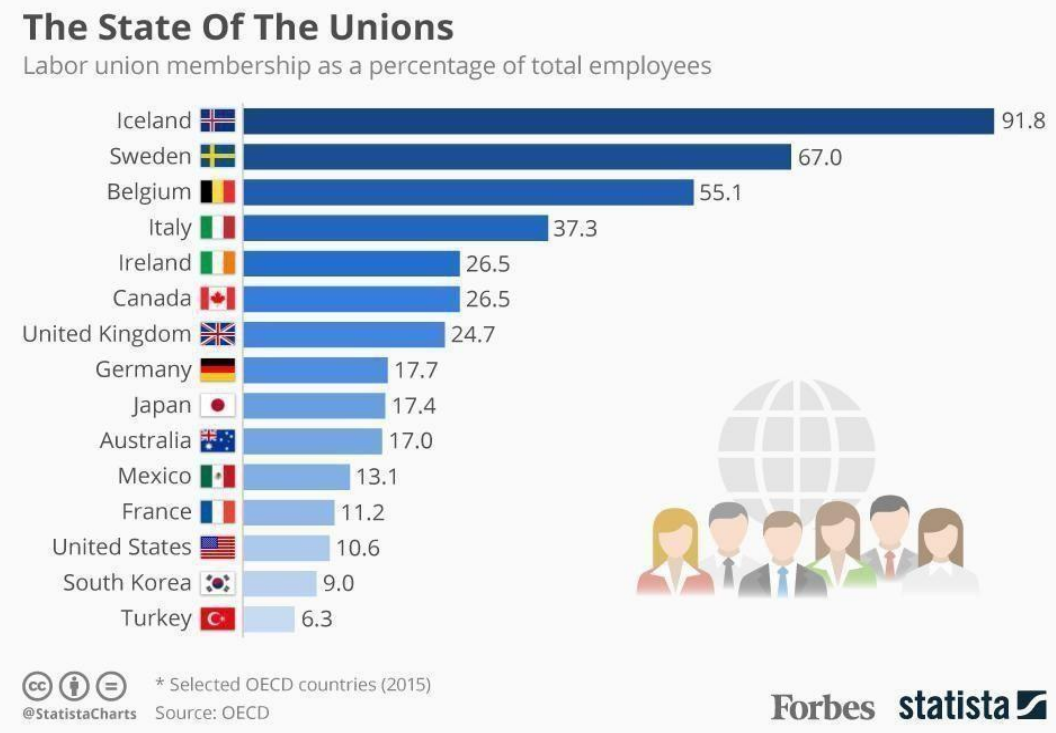

Source: Organization for Economic Co-operation and Development

From the graph it can be seen that the top labour union activity is seen in the countries of Europe and USA is at the bottom of the table

\section{Role of European Union}

The European Union is a political and economic group of 28 countries in Europe that cover most of the Europe we are trying to cover in the paper. It binds these group of countries to work together for overall development of these nations.

One of the concerns of the European Union is to also look after the income inequality. It is often regarded by many as the preserver of "Europe's social model". The European
Union has also avoided the conversion of market economy into a market society as in the US. This has resulted in better policies for the poor in Europe.

As discussed earlier, inequality everywhere including the countries of the European Union is rising. A few countries like Romania and Bulgaria have high numbers of inequality. However, upon inspection of the following graph, it is quite evident that the United States of America has more inequality than all the nations of the European Union for the past many years and even today.

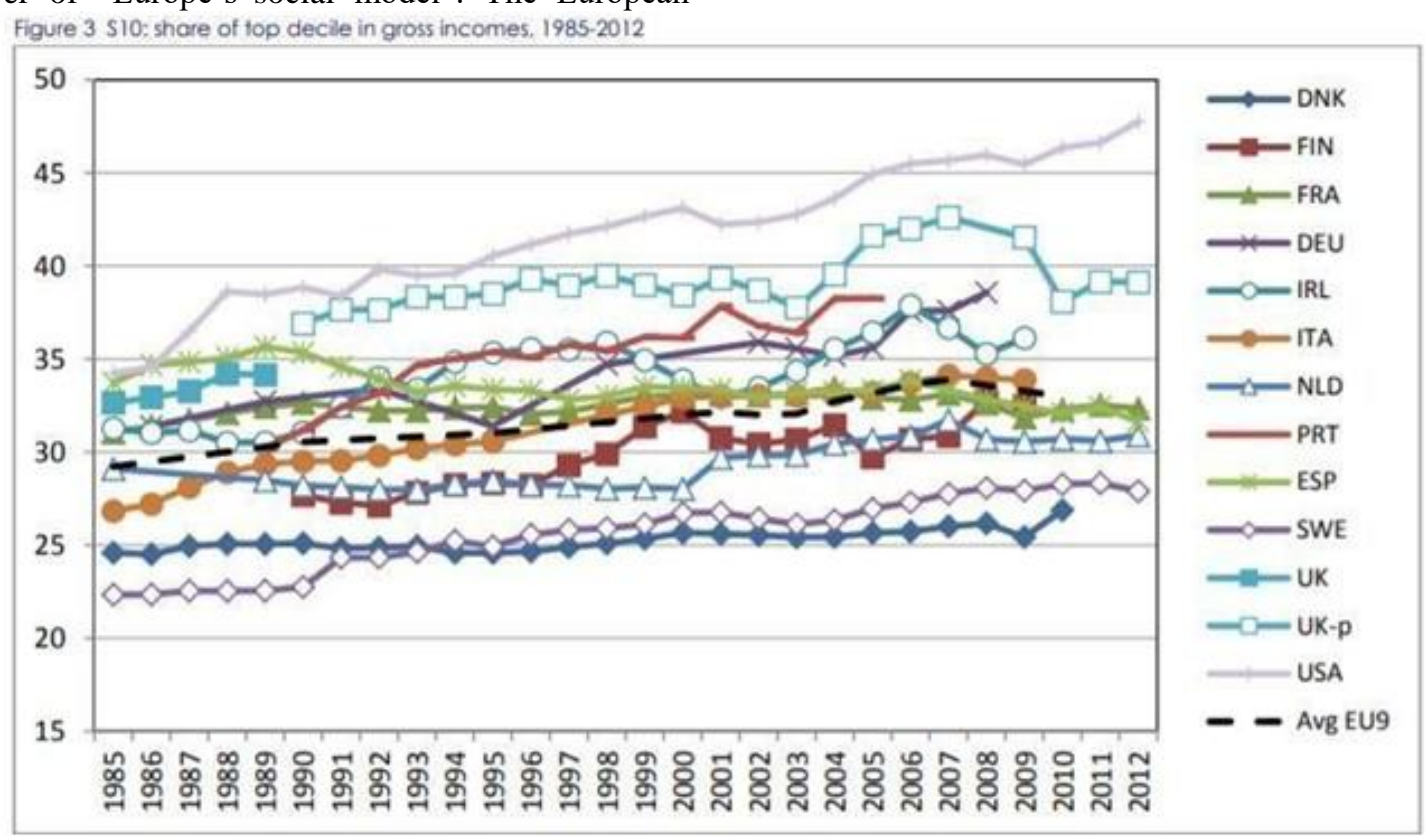

Share of top decile in gross incomes, 1985-2012

Source: EU Policy Making and Growing Inequalities, Wiemer Salverda, 2015 
The European Union and its steps towards reducing inequality has played a major role in this. In many European countries of the EU, inequality is assumed to below because of the pre-distributive policies that empower the labour. There are national minimum wages and other protective labour rights. The European Union is not directly involved in the decision making of each country, it is just politically determined towards a particular problem and leaves the policy making for the countries to the respective states themselves. This is why some differences in data are found even amongst the members of the Union.

Clearly it is no coincidence that almost all the countries of the European Union have the lowest Gini coefficients amongst all countries in the world. A value of Gini coefficient greater than $50 \%$ (not far off from Latin America) is an alarming situation. The values for various countries can be found here. Clearly, the European Union has worked well towards removing inequality in Europe.

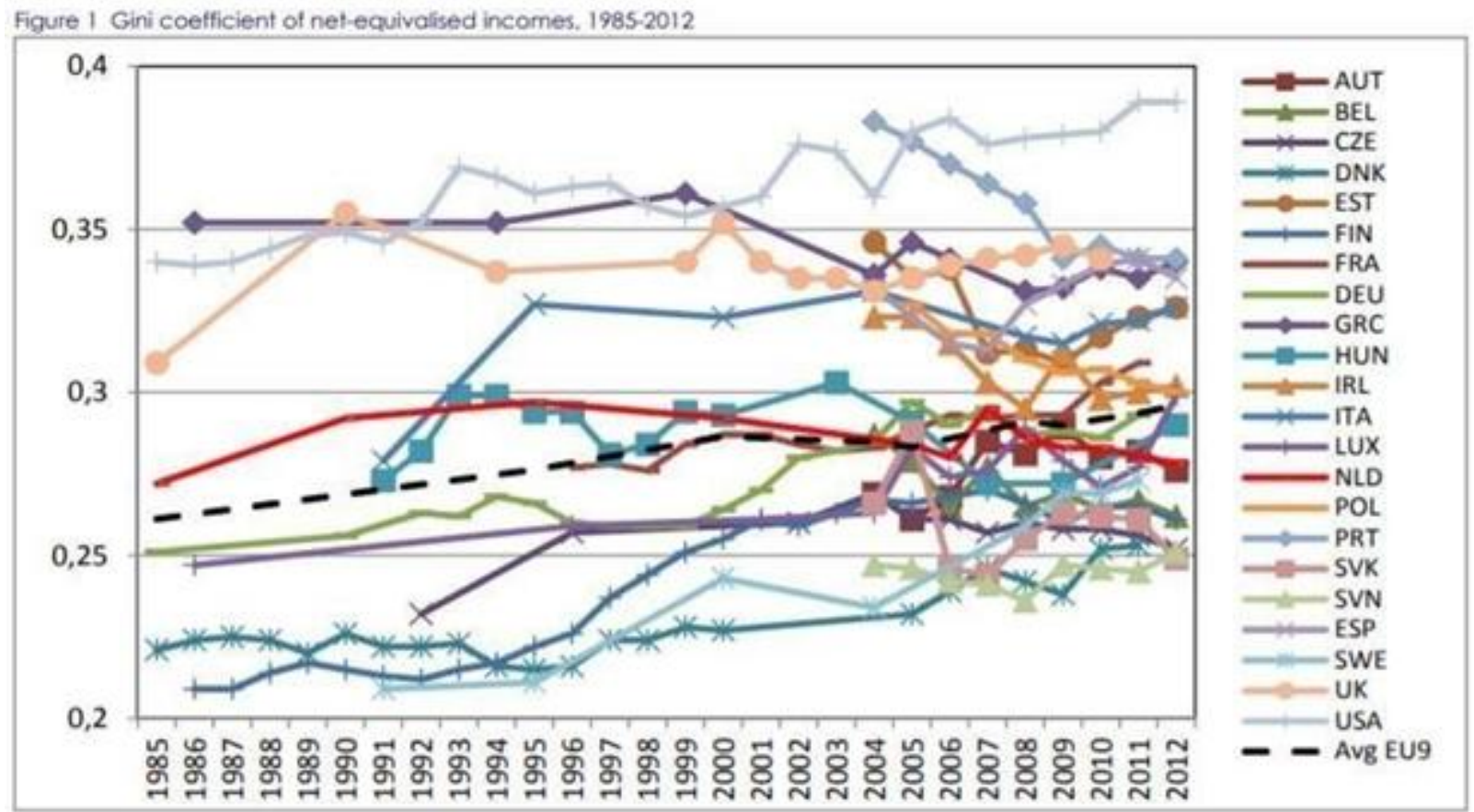

Note: EU9 average concerns Denmark, Finland, Germany, Greece, Italy, Luxembourg. Netherlands, Sweden and the UK.

Gini Coefficient of Several Countries

Source: EU Policy Making and Growing Inequalities, Wiemer Salverda, 2015

\section{The World Learning from Europe}

Though there is a big difference in the amount of inequality in US and Europe, itis still increasing. Nations across the world are trying to reduce inequality. Many measures are being tried to be implemented from tax reforms to human capital development of the poor. Even US President Joe Biden plans to lower inequality by introducing a big tax increase as in the already existing case of Europe. The Nordic nations of Europe, namely Denmark, Sweden and Norway have the least inequality and is seen to have the highest percentage of happy people in the country. These nations serve as an ideal model for removing inequality around the world.

\section{Conclusion}

Since the advent of capitalism and globalization in the late 20 th century, inequality across the world has seen a rise. The poorer sections of the society are suffering. This is a problem for many nations as economic growth is often found to be negatively related to inequality [3]. As many countries strive to reduce inequality, it will be interesting to see how they go on in their approach.

\section{Citations}

[1] Michael W. Howard (2007), https://www.britannica.com/topic/income- inequality

[2] Ana Maria Santacreu(2017), How does U.S. Income Inequality Compare Worldwide, https://www.stlouisfed.org/on-theeconomy/2017/october/how-us-income-inequalitycompare- worldwide

[3] Mala Das, Muhibbullah (2019), The Impact of Inflation on the Income Inequality of Bangladesh: A Time Series Analysis,

https://www.researchgate.net/publication/333386135_T he_Impact_of

[4] _Inflation_on_the_Income_Inequality_of_Bangladesh_ A_Time_Series_Analysis

[5] The Productivity-Pay Gap https://www.epi.org/productivity- pay-gap/

[6] Lawrence Mishel (2012), The wedges between productivity and median compensation growth, https://www.epi.org/publication/ib330- productivity-vscompensation/

[7] Education, Causes of inequality in the United States, https://en.wikipedia.org/wiki/Causes_of_income_inequa lity_in_the_U nited_States\#Divergence_of_productivity_and_compen 
sation

[8] Susan E. Mayer (2010), The relation between income inequality and inequality in schooling

[9] Michael Linden (2012), The Federal Tax code and Income Inequality, https://www.americanprogress.org/issues/economy/repo rts/2012/04/ 19/11404/the-federal-tax-code-andincome-inequality/

[10] Heather Boushey, Carter Price (2014), How are income inequality and growth connected? https://equitablegrowth.org/economic-inequalitygrowth-connected/

\section{References}

[11] Michelle Jackson, Brian Holzman (2020), A century of educational inequality in the United States, https://www.pnas.org/content/117/32/19108

[12] Chichun Fang (2018) Growing Wealth Gaps in Education, https://www.src.isr.umich.edu/growingwealth-gaps-in-education/

[13] Nick Hanauer (2019), Better schools won't fix America, https://www.theatlantic.com/magazine/archive/2019/07/ed ucation- isnt-enough/590611/

[14] (2020), New tool examines how US taxes and spending affect income inequality, https://www.epi.org/press/new-tool-examines-how-u-staxes-and-spending-affect-income-

inequality/\#: :text=While $\% 20$ the $\% 20$ federal $\% 20$ tax $\% 2$ 0system,to\%20st ate \%20and\%20local\%20governments

[15](2020), The gap between real labour productivity and wage growth, https://www.epi.org/press/new-toolexamines-how-u-s-taxes-and- spending-affect-incomeinequality/\#: :text=While $\% 20$ the $\% 20$ federal $\% 20$ tax $\% 20 \mathrm{~s}$ ystem,to\%20st ate\%20and\%20local\%20governments

[16] Scott Horsley (2019), Why America's 1-Percenters are Richer than Europe's, https://www.npr.org/2019/12/05/783001561/why-

americas-1- percenters-are-richer-than-europes\#: :text=Since\%201980\%2C\%20the\%20share\%20of,only \%20modestly\% 2C\%20to\%2018\%25

[17] Thomas Blanchet, Lucas Chancel, Amory Gethin (2019), Why US Inequality is Higher Than Europe's, https://www.project- syndicate.org/commentary/europeamerica-income-inequality-lessons-by- thomas-blanchetet-al-2019-11?barrier=accesspaylog

[18] Ana Maria Santacreu, Heting Zhu (2017), How does US Income Inequality compare worldwide? https://www.stlouisfed.org/on-theeconomy/2017/october/how-us-income-inequalitycompare-worldwide

[19] Max Roser, Esteban Ortiz-Ospina (2017), How does US Income Inequality compare worldwide? https://www.stlouisfed.org/on-theeconomy/2017/october/how-us-income-inequalitycompare-worldwide 